\title{
Redaktørernes forord
}

Temaet for dette, ekstraordinært omfattende, nummer er komparativ metode. Emnet diskuteres både generelt og via en række aktuelle eksempler på dansk / skandinavisk/international komparativ forskning af forskellig slags. Fem artikler, en kommentar, et review-essay og et par af anmeldelserne er viet til dette formål. Initiativtagere og gæsteredaktører er Per H. Jensen, AAU og Peter Wad, HHK.

Emnet er vigtigt, interessant og aktuelt. Det er hele tiden vigtigt at reflektere over de komparative metoder, fordi komparative metoder siden Marx, Weber og Durkheim fortløbende har udgjort en central bestanddel i sociologiens værktøjskasse. Man kan hævde principielt, at al samfundsforskning er komparativ, da al empiri og analyse bygger på sammenligninger i en eller anden forstand. Eller man kan bruge betegnelsen for studier, der sammenligner flere sociale helheder (cases), og dermed overskrider enkelt-case studiets unikke karakter og induktive/ generaliserende faldgruber på den ene side, og kvantitative survey-undersøgelsers helhedsnedbrydende tilgang på den anden side.

Emnet er interessant, fordi komparative metodediskussioner har været mere eller mindre fraværende i nyere dansk sociologisk debat. Danske sociologer har i 1980erne og 1990erne været mere optaget af modsætningen mellem kvantitative og kvalitative metoder, en kritisk udvikling af kvalitative metoder (Dansk Sociologi årgang 6 nr. 4, 1995) og forsøgene på at slå bro over denne metodekløft ved at kombinere de to typer metoder efter forskningens formål og problemstilling
(Enderuds 'tredje bølge' i 1980erne).

Og emnet er aktuelt, fordi der synes at være en stigende interesse for komparative undersøgelser og metodeproblematikker i dansk og international sociologi under indtryk af den europæiske regionale integrationsproces og den omsiggribende globalisering.

Vi lægger ud med artiklen "Komparation $\mathrm{i}$ kritisk realistisk perspektiv" af $\mathrm{Pe}$ ter Wad. I artiklen diskuterer forfatteren de mulige og potentielt frugtbare, gensidige koblinger mellem videnskabsteoretiske problemstillinger og komparative metoder. Dette gøres med udgangspunkt i den kritiske realisme, der er en nyere videnskabsfilosofi, som er udformet i England omkring filosoffen Roy Bhaskar siden 1970erne, og som har fået et gennembrud i svensk sociologi inden for de seneste år. Spørgsmålet er, om kritisk realisme kan bidrage til videreudviklingen af sociologisk komparation? Efter en kort præsentation af kritisk realisme og dens sociologiske metodologi konstaterer forfatteren, at man ikke har formuleret en særlig kritisk realistisk komparation, selvom komparativ metode fremhæves som en meget vigtig metode. Man henviser til den eksisterende komparative tradition, men denne tradition viser sig helt frem til 1990erne at være rodfæstet i John Stuart Mill's komparative logik fra 1843! Trods dette slægtskab med engelsk empirisme konkluderer artiklen, at et par af de nyeste komparative metodikker kan bidrage til formuleringen af en genuin kritisk realistisk komparativ metodologi.

Herefter bringes 3 artikler, der har det 
til fælles, at de er empirisk orienterede, at de gennemfører tværnationale komparative analyser, og at de omhandler velfærdsmæssige problemstillinger.

Per H. Jensen's artikel "Kontekstuelle og tværnationale komparative analyser" forsøger at bygge bro mellem teori og empiri i en socialkonstruktivistisk inspireret komparativ analysestrategi. Dermed er formålet at få præciseret den kontekstuelle metodologi, der indebærer, at vi i vore observationer af personer og institutioner må tage afsæt $\mathrm{i}$ begrebsdannelser om det enkelte samfunds helhed. Dvs. vore teoretiske konstruktioner af verden må fungere med en forpligtende og tvingende logik, der skal organisere og strukturere vor forståelse af egenskaber ved individerne og personerne i den kontekst, der er under observation. Der udvikles en kontekstuel begrebsmodel, og modellens logiske holdbarhed testes empirisk. Forskellene i kvinders erhvervsdeltagelse i Danmark og Italien fungerer som det gennemgående eksempelmateriale.

Det særlige ved de 2 øvrige artikler, der i et tværnationalt perspektiv behandler velfærdsmæssige problemstillinger, er, at de forsøger at afprøve og demonstrere nytten af nye komparative metoder.

Artiklen "Socialpolitik eller social struktur? Inkomsttransfereringar, sociodemografiska faktorer och fattigdom i Frankrike och de nordiska länderna" af Olli Kangas og Veli-Matti Ritakallio sammenligner socialpolitikkens resultater i Frankrig og de nordiske lande (Danmark, Norge, Sverige og Finland). Efter en beskrivelse af fattigdommens karakter og udbredelse analyseres fattigdomseffekten af indkomstoverførsler, først landevis og derefter ved at sammenligne Frankrig med en sammenlagt 'skandinavisk model'. Formålet er her at vurdere socialpolitikkens gennemslagskraft i hhv. Frankrig og 'Skandinavien', såfremt politikken virkede under samme sociodemografiske strukturer. Sammenligningen simuleres statisk og dynamisk, og forfatterne konkluderer, at forskelle i fattigdom forklares mere ved forskelle i socio-demografiske strukturer end ved socialpolitiske forskelle, dog med forbehold for velfærdsstatens institutionelle udformning.

Jon Kvist tager med "Idealtyper og fuzzy mængdelære i komparative studier - konceptualisering, konfiguration og kategorisering" fat på denne nye lære og dens anvendelsesmuligheder i samfundsforskningen. Forfatteren argumenterer, at 'fuzzy logik' er særlig velegnet til komparative studier af diversitet, dvs. forskelle og ligheder inden for et mellemstort antal cases. Den muliggør operationalisering af teoretiske begreber, opstilling af idealtyper, og analyse af empiriske cases i forhold til idealtyper. I en beskrivelse af den familiepolitiske udvikling i de nordiske lande i 1990erne, sammenholdt med den idealtypiske socialdemokratiske familiepolitiske model, viser artiklen, hvordan fuzzy mængdelæren kan bruges i praksis, og hvad dens komparative fordele går ud på i forhold til kvalitative case-studier og kvantitative variabel-studier.

Den sidste tema-artikel er Jan Hjarnø's "Indvandrere som selverhvervende - en sammenlignende analyse af udbredelsen af selverhverv hos danske pakistanere, tyrkere og eksjugoslavere". Den repræsenterer et komparativt studie af forskellige befolkningsgrupper i samme nationale kontekst. Med afsæt i Thomas Højrup's livsformshypotese søger forfatteren at afdække sociale og kulturelle forskelle, der kan forklare forskelle i selverhverv blandt forskellige indvandrergrupper i Danmark. Til trods for at de kom til landet næsten samtidig og har haft samme muligheder, er der markante forskelle 
i såvel selverhvervsfrekvens som i de selverhvervendes bruttoindkomst blandt de tre undersøgte grupper. Sammenlignes grupperne over flere årtier viser det sig, at deres livsformer i oprindelseslandet spiller en afgørende rolle for, om 'medlemmerne' etablerer sig som selvstændige erhvervsdrivende i Danmark, og hvad de får ud af det i økonomisk forstand.

Kommentaren "Komparative metoder - kausalitet eller kontekst?" af Jens Tonboe søger først tilbage til grundlaget for komparative metoder i sociologien, til Durkheim, der mere end nogen anden bidrog til at lancere metoden som uomgængelig. Hvad mente han egentlig dermed hvad ville han opnå - og undgå? Herfra trækkes der en parallel til en mere nutidig diskurs for at demonstrere, at Durkheims problemstilling stadig er aktuel og uafklaret! Dermed introduceres også den videnskabsteoretiske baggrund for kausalitetsopfattelser af forskellig slags, som ligger bag diskussionerne om sammenligningers nødvendighed og umulighed. Og herudfra rejses der faktisk flere spørgsmål end der afklares.

Jørgen Goul Andersen's review-essay beskæftiger sig med fire 'typiske' udgivelser inden for de sidste 10 års næsten eksplosive komparative velfærdsstatsforskning. Det gælder Gøsta Esping-Andersens nye hovedværk og tre samleværker. Review-essayet viser, at den nyere komparative velfærdsstatsforskning er leveringsdygtig i problem-identificering og teoretiske forklaringer samt i normative vurderinger af forskellige muligheder for velfærdsstaters udformning. Men essayisten argumenterer, at denne tendens kan føre til en uhensigtsmæssig sammenblanding af det analytiske og det normative perspektiv, og at velfærdsstatsforskningen faktisk afpolitiseres i retning af en ubevidst funktionalisme. Konklusionen er, at velfærdsstatsforskningen bør repolitiseres.
Også blandt anmeldelserne er der to udgivelser af komparativ interesse, om end de ikke er skrevet ud fra et komparativt eller metodisk temaperspektiv (alene).

Alt $i$ alt mener vi, at temanummeret bidrager til at (gen)introducere dette atter aktuelle tema, og at det forhåbentlig hermed inviterer til yderligere diskussion og udvikling på området. Specielt mener vi, at spørgsmålene om komparationens videnskabsteoretiske, teoretiske og historiske forudsætninger er vigtige at få belyst og, om muligt, midlertidigt afklaret. Det er også væsentligt at videreudvikle og forfine specifikke komparative metoder i forhold til problemstillinger af mere praktisk og anvendelsesorienteret art. Lige som internationalisering og globalisering synes at stimulere interessen for komparativ sociologisk forskning, så rejser denne forandringsproces samtidig spørgsmålet om komparationens sociologiske (ir)relevans: Kan man overhovedet sammenligne (samfund), hvis alt smelter sammen i et (globalt) socialt system? Hvis ja, hvad kan man sammenligne, hvordan og med hvilket formål? Hvis nej, hvilken eller hvilke metoder kan da afløse komparationen som sociologiens fremmeste metode? $\mathrm{Og}$ kunne man i øvrigt overhovedet meningsfuldt sammenligne sociale forhold fra forskellige, isolerede kontekster? Hænger tingene lige frem sammen på en sådan måde, at den pågående, hurtige nedbrydning af grænser mellem relativt autonome eller isolerede stater og samfund netop muliggør og nødvendiggør i det mindste makro-komparativ sociologisk forskning, mens samme grænseoverskridende proces med tiden vil svække eller umuliggøre komparative forskning - og dermed kernen i sociologiske studier? Hermed ønsker vi læserne god fornøjelse.

Per H. Jensen, Peter Wad og Jens Tonboe 